\title{
Health-related quality of life of parents of children with phenylketonuria in Tehran Province, Islamic Republic of Iran
}

Koorosh Etemad, ${ }^{1}$ Alireza Heidari, ${ }^{2}$ Aria Setoodeh, ${ }^{3}$ Amir Shayeganrad, ${ }^{4}$ Atoosa Akhlaghi, ${ }^{5}$ Maryam Azizi, ${ }^{6}$ Roya Nejatbakhsh,${ }^{7}$ Maryam Beheshti Beglar ${ }^{8}$ and Mansoureh Lotfi ${ }^{9}$

${ }^{1}$ Environmental and Occupational Hazards Control Research Center, Faculty of Public Health, Shahid Beheshti University of Medical Sciences, Tehran, Islamic Republic of Iran. ${ }^{2}$ Health Management and Social Development Research Center, Golestan University of Medical Sciences, Gorgan, Islamic Republic of Iran. ${ }^{3}$ Children's Medical Center, Tehran University of Medical Sciences, Tehran, Islamic Republic of Iran. ${ }^{4}$ Deputy of Students Affairs, Tehran University of Medical Sciences, Tehran, Islamic Republic of Iran. ${ }^{5}$ Islamic Azad University, Science and Research Branch, Tehran, Islamic Republic of Iran. ${ }^{6}$ Islamic Azad University, Science and Research Branch, Tehran, Islamic Republic of Iran. ${ }^{7}$ Ali Asghar Hospital, Iran University of Medical Sciences, Tehran, Islamic Republic of Iran. ${ }^{8}$ Mofid Children's Hospital, Shahid Beheshti University of Medical Sciences, Tehran, Islamic Republic of Iran. 'Office of Knowledge Translation and Research Utilization, Deputy of Research and Technology, Tehran University of Medical Sciences, Tehran, Islamic Republic of Iran (Correspondence to: Alireza Heidari: alirezaheidari@gmail.com).

\begin{abstract}
Background: Parents of children with phenylketonuria are at risk of reduced quality of life.

Aims: This study determined the quality of life of parents of children with phenylketonuria in Tehran Province.

Methods: The study was conducted in 2015 and included parents of children with phenylketonuria referred to three government children's hospitals in Tehran Province that provide phenylketonuria services. Data were collected using the Farsi version of the World Health Organization Quality of Life-Bref questionnaire. Analysis of variance, t-test, Pearson correlation coefficient and multiple linear regression were used to assess the relationship between quality of life domains and sociodemographic characteristics of the parent and child.
\end{abstract}

Results: The study included 240 parents; 55\% were mothers. Quality of life of parents in psychological, social relationships and environment domains was low. Significant relationships were found between: physical domain and age of child at phenylketonuria diagnosis $(P=0.044)$; psychological domain and parent's age $(P=0.019)$, child's age $(P=0.007)$ and parent's education $(P=0.015)$; social relationships domain and parent's age $(P=0.003)$, and education $(P=0.002)$, household income $(P=0.025)$ and child's age $(P=0.004$; and environmental domain and residence $(P=0.034)$, parent's education $(P=0.007)$, household income $(P=0.002)$ and child's age $(P=0.049)$. In the multivariable analysis, parent's age and education, child's age, and household income were significantly associated with parent's quality of life.

Conclusion: Given the low levels of quality of life in the parents, education and more financial support are recommended. Keywords: quality of life, parents, phenylketonuria, Iran

Citation: Etemad K; Heidari A; Setoodeh A; Shayeganrad A; Akhlaghi A; Azizi M et al. Health-related quality of life of parents of children with phenylketonuria in Tehran Province, Islamic Republic of Iran. East Mediterr Health J. 2020;26(3):331-339. https://doi.org/10.26719/emhj.19.045

Received: 28/01/18; accepted: 08/08/18

Copyright @ World Health Organization (WHO) 2020. Open Access. Some rights reserved. This work is available under the CC BY-NC-SA 3.0 IGO license (https://creativecommons.org/licenses/by-nc-sa/3.o/igo),

\section{Introduction}

Phenylketonuria is an autosomal recessive disorder of amino acid metabolism. The enzyme phenylalanine hydroxylase is necessary to metabolize the amino acid phenylalanine to tyrosine in liver. This enzyme is defective in people with phenylketonuria. It leads to an increase of phenylalanine in the blood and the brain (1). High levels of phenylalanine in the plasma cause mental retardation, seizures, behavioural difficulties, motor delay and slow language development. Although children with phenylketonuria who are treated early have average intelligence, they differ in cognitive performance when compared with their peers without phenylketonuria. Academic and cognitive functions of children with phenylketonuria are significantly lower than peers in the control group (2). It has also been reported that children with phenylketonuria may have low self-esteem, less motivation, loss of independence and reduced social confidence. Adolescents and adults may be at risk of depression, anxiety and social isolation (3).
Lifelong dietary treatment from birth is required to prevent mental retardation for all patients with phenylketonuria. Treatment includes severe restriction of natural protein, and supplementation with the phenylalanine-free formula (4). Adhering to the diet for people with phenylketonuria is a burden for patients and health staff, and management of phenylketonuria can be time-consuming for both adult patients and caregivers of children. In addition, phenylalanine intake should be monitored carefully by regular blood tests. Phenylketonuria may also impose an economic burden on patients and caregivers. These costs include direct costs related to the resources needed for the management of phenylketonuria, such as low-protein foods, supplements, medications, laboratory monitoring and visits to health care services, and also indirect costs in loss of productivity (5).

In the past two decades, studies to assess the quality of life (QoL) of people with chronic conditions have increased (6). Health-related QoL is the effect of disease 
and treatment on physical, psychological, social and welfare dimensions of life (7). Health-related QoL can be used in the evaluation of disease outcomes, the use of interventions, assessment of the effectiveness of different treatments, and evaluation of health care services and health policies (8).

With early detection and treatment, phenylketonuria is a relatively benign disease, without physical symptoms and with few hospitalizations (9). However, the need to regularly monitor blood and adapt to a more complex diet, and the occurrence of neurological symptoms and stigma associated with a congenital metabolic disorder are likely to affect the QoL of people with phenylketonuria and their parents (10).

Assessment of QoL in these parents can help identify those with undiagnosed disorders as a result of the chronic burden of caring for a child with phenylketonuria. In addition to the usual stress associated with caring for a newborn baby, parents have to cope with the grief and worry of having a sick child and having to learn how to manage the diet (11). Parents of children with chronic diseases are at risk of psychological disorders and mental problems and have lower health status than parents of healthy children (12). In addition, a study that compared the QoL of parents of sick children and parents of healthy children showed that more than half of the parents of children with chronic diseases were at risk of decreased QoL (13).

The incidence of phenylketonuria in the Islamic Republic of Iran is relatively high (2) and studies on the QoL of parents of children with phenylketonuria are lacking. Therefore, this study aimed to determine the QoL of parents with children with phenylketonuria in Tehran Province.

\section{Methods}

This was a cross-sectional study conducted in three hospitals in Tehran Province in 2015: Children's Medical Centre, Mofid Hospital and Aliasghar Hospital. These three government hospitals are the only children's hospitals that provide specialized services to patients with phenylketonuria in Tehran Province. Using census sampling, all 240 parents (mother or father) referred to these hospitals from March to December 2015 were included in the study. The inclusion criteria were: Iranian nationality, father or mother of children with phenylketonuria, residence in Tehran Province, and ability to respond to the questionnaire. Exclusion criteria were: unwillingness to participate in the study and inability to remember events that had occurred in the past four weeks which were asked about in the questionnaire.

The World Health Organization Quality of Life-Bref (WHOQOL-BREF) was used to evaluate QoL. This 26item questionnaire includes four domains: physical health (seven items), psychological health (six items), social relationships (three items) and environment (eight items). It also has two general questions about the individual's overall perception of his/her QoL and overall perception of his/her health. Each item is rated on a fivepoint Likert scale from 1 to 5 and, to convert domain scores to a 0-100 scale, raw scores are converted to transformed scores (14). As per the WHOQOL-BREF manual, the mean score of items was used to compute the domain score. A higher score indicates a better QoL. The validity and reliability of the Farsi version of this questionnaire have been demonstrated (15-17). In our study, the validity of the instrument was confirmed by expert opinion and its reliability was acceptable (Cronbach alpha $=0.95)$.

\section{Statistical analysis}

Data were analysed using SPSS, version 22.0. A P-value less than 0.05 was considered statistically significant. Means and standard deviations (SD) were computed for demographic variables. Analysis of variance (ANOVA), t-test, Pearson correlation coefficient and multiple linear regression were used to assess the relationship between quality of life domains and sociodemographic characteristics of the parent and child.

\section{Ethical considerations}

The study was approved by the Committee for Ethics of Faculty of Public Health of Shahid Beheshti University of Medical Sciences (Code SBMU.REC.1393.812). The purpose of the study and procedures that would be carried out were explained to the parents of the children and verbal informed consent was obtained.

\section{Results}

A total of 240 parents completed the questionnaires, 55\% were mothers and $45 \%$ were fathers. The mean ages of the parents and their children were 36.82 (SD 7.8) and 8.73 (SD 8.1) years respectively. Most of the parents (89.6\%) were married, $49.8 \%$ were housewives, $42.2 \%$ had high-school education, $49.3 \%$ earned US\$ 295 or less a month and $51 \%$ lived in Tehran city. As regards the number of children with phenylketonuria in the family, 90.5\% had one child, 9.1\% had two children and one family had four children with phenylketonuria. Most of the children (55.8\%) were boys. Only $52.8 \%$ of the patients had been diagnosed early; the mean age at diagnosis was 14 (SD 26) months (range 1 day-9.8 years). The demographic characteristics of parents and their children with phenylketonuria are shown in Table 1.

Most of the parents $(43.6 \%)$ had an average perception of their overall QoL and a low perception of their health status. The mean score for overall perception of QoL was 2.92 (SD 1.1, range 1-5), and mean score for perception of health was 2.51 (SD 1, range 1-5).

The mean scores of the parents for physical health, psychological health, social relationships and environment were 21.23 (SD 2.5), 17.40 (SD 3.8), 7.96 (SD 2.4) and 19.79 (SD 2.9) respectively (Table 2). The highest mean score was for physical health (transformed score 50) and the lowest mean score was for environment (transformed score 38) (Table 2).

There was a significant relationship between 
psychological dimension and parent's age $(P=0.019, r=$ -0.158), child's age $(P=0.007, r=-0.183)$ and education level of the parent $(P=0.015)$. There was also a significant relationship between social relationships dimension and parent's age $(P=0.003, r=0.2)$, education $(P=0.002)$, child's age $(P=0.004, r=-0.188)$, and household income $(P=0.025)$. There was a significant relationship between the environment dimension and residence $(P=0.034)$, household income $(P=0.002)$, education level of the parent $(P=0.007)$, and child's age $(P=0.049, r=-0.130)$. No significant relationship was found between QoL domains and the hospitals, relation of parent to the child, sex of child, employment and number of children with phenylketonuria. Variables associated with QoL domains are shown in Table 3.

In the multivariable linear regression analysis, parent's age was a predictor of the physical dimension of QoL; Parent's education level and child's age were predictors of the psychological and the social relationships dimensions of QoL; and household income was predictor of QoL in the environment dimension (Table 4).

\section{Discussion}

Our study found a low level of QoL in parents of children with phenylketonuria in Tehran Province. A study in the Netherlands also found low health-related QoL in the parents of children with phenylketonuria (18). In a survey conducted in the Islamic Republic of Iran, caregivers of patients with phenylketonuria had a lower QoL level than the general population (19). In contrast to our study, other results were not consistent $(7,12)$. Having mentally impaired children in the family, in addition to causing psychological stress, can cause physical illness, such as pain, and mental disorders, such as depression and anxiety, in families, which lead to reduced QoL of mothers $(20,21)$. The reasons for differences between our study and others could be variations in the population, social and cultural conditions of communities, and the presence of support organizations.

Our findings indicate that parents with older children had lower QoL with regard to psychological health. This is not consistent with the results of other studies which found older age of the child was associated with a better health-related QoL in parents $(7,12)$.With increasing patient age, controlling and caring for the disease can become costly and tedious. Most of the time, adherence to treatment decreases with increasing age because of low awareness of dietary restrictions, weak motivation and inability to comply with treatment (22). Non-compliance with diet in low- and middle-income countries can be due to a lack of experienced support centres, larger families, neglect of parents, financial constraints, low perception of risk in parents, and limited availability of low-protein products (23). Parents with children who had been diagnosed early had better QoL for physical and psychological health. Patients who are treated early generally have a favourable outcome with normal development (24). People with phenylketonuria
Table 1 Distribution of the parents and patients with phenylketonuria according to demographic characteristics

\begin{tabular}{|c|c|}
\hline Variable & $\begin{array}{c}\text { No. (\%) } \\
(n=240)\end{array}$ \\
\hline \multicolumn{2}{|c|}{ Parents } \\
\hline \multicolumn{2}{|l|}{ Hospital } \\
\hline Children's Medical Centre & $91(37.9)$ \\
\hline Mofid & $81(33.8)$ \\
\hline Aliasghar & $68(28.3)$ \\
\hline \multicolumn{2}{|l|}{ Age (years) } \\
\hline$\leq 30$ & $49(20.4)$ \\
\hline $31-40$ & $121(50.4)$ \\
\hline $41-50$ & $51(21.3)$ \\
\hline$>51$ & $19(7.9)$ \\
\hline \multicolumn{2}{|l|}{ Relation to child } \\
\hline Father & $108(45.0)$ \\
\hline Mother & $132(55.0)$ \\
\hline \multicolumn{2}{|l|}{ Marital status } \\
\hline Married & $215(89.6)$ \\
\hline Divorced or widowed & $25(10.4)$ \\
\hline \multicolumn{2}{|l|}{ Education $^{a}$} \\
\hline Illiterate & $3(1.3)$ \\
\hline Elementary school & $26(11.2)$ \\
\hline Middle school & $41(17.7)$ \\
\hline High school & $98(42.2)$ \\
\hline University & $64(27.6)$ \\
\hline \multicolumn{2}{|c|}{ Monthly household income ${ }^{a}$ (US\$̦) } \\
\hline$\leq 295$ & $104(49.3)$ \\
\hline $295-442.5$ & $44(20.8)$ \\
\hline $442.5-590$ & $19(9)$ \\
\hline$>590$ & $44(20.9)$ \\
\hline Residence & \\
\hline Tehran city & $122(50.8)$ \\
\hline Outside Tehran city & $118(49.2)$ \\
\hline Number of children in family $u$ & \\
\hline 1 & $210(90.5)$ \\
\hline 2 & $21(9.1)$ \\
\hline 4 & $1(0.4)$ \\
\hline Employment $^{a}$ & \\
\hline Housewife & $113(49.8)$ \\
\hline Former employee & $45(19.8)$ \\
\hline Manual worker & $22(9.7)$ \\
\hline Other & $47(20.7)$ \\
\hline & \\
\hline Age (years) & \\
\hline$\leq 1$ & $36(15.0)$ \\
\hline $1-5$ & $66(27.5)$ \\
\hline $6-10$ & $65(27.2)$ \\
\hline $15-11$ & $33(13.8)$ \\
\hline $16-20$ & $19(7.9)$ \\
\hline$>20$ & $21(8.7)$ \\
\hline
\end{tabular}


Table 1 Distribution of the parents and patients with phenylketonuria according to demographic characteristics (concluded)

\begin{tabular}{|lc}
\hline Variable & $\begin{array}{c}\text { No. (\%) } \\
(\mathbf{n}=\mathbf{2 4 0})\end{array}$ \\
\hline Sex & \\
$\quad$ Male & $134(55.8)$ \\
Female & $106(44.2)$ \\
Age at diagnosis of phenylketonuriaa & \\
\hline 3-5 days & $122(52.8)$ \\
$>5$ days & $109(47.2)$ \\
\hline
\end{tabular}

aTotal is less than 240 because of missing values. who are treated at an early age generally have an IQ in the normal range (25). Therefore, patients with late diagnosis are faced with mental and physical disabilities that affect all family members.

Tehran residents had a lower QoL in the environmental dimension compared with other towns of Tehran province. Another Iranian study found the environmental dimension scores in different age groups in Tehran city population were significantly lower than in other parts of the world (26). A study in 2008 indicated that personal security and public services have an important role in people's QoL (27). According another Iranian study, the quality of life will

Table 2 Mean scores of the parents of children with phenylketonuria in the World Health Organization Quality of Life-BREF (WHOQOL-BREF) domains

\begin{tabular}{|c|c|c|c|c|c|}
\hline \multirow[t]{2}{*}{ Domain } & Raw score & \multirow[t]{2}{*}{ Min-Max } & \multirow{2}{*}{$\begin{array}{l}95 \% \text { confidence } \\
\text { interval }\end{array}$} & \multicolumn{2}{|c|}{ Transformed score } \\
\hline & Mean (SD) & & & $4-20$ & $0-100$ \\
\hline Physical & $21.23(2.5)$ & $14-27$ & $20.92-21.55$ & 12 & 50 \\
\hline Psychological & $17.40(3.8)$ & $8-27$ & $16.89-17.84$ & 11 & 44 \\
\hline Social relationships & $7.96(2.4)$ & $3-14$ & $7.46-8.27$ & 11 & 44 \\
\hline Environment & $19.79(2.9)$ & $11-27$ & $19.41-20.16$ & 10 & 38 \\
\hline
\end{tabular}

SD: standard deviation.

Table 3 Variables associated with quality of life domains of parents of children with phenylketonuria

\begin{tabular}{|c|c|c|c|c|}
\hline \multirow[t]{2}{*}{ Variable } & \multicolumn{4}{|c|}{ Domains } \\
\hline & $\begin{array}{l}\text { Physical Mean } \\
\text { (SD) }\end{array}$ & $\begin{array}{l}\text { Psychological Mean } \\
\text { (SD) }\end{array}$ & $\begin{array}{c}\text { Social relationships } \\
\text { Mean (SD) }\end{array}$ & $\begin{array}{l}\text { Environment Mean } \\
\text { (SD) }\end{array}$ \\
\hline \multicolumn{5}{|l|}{ Hospital } \\
\hline Children's Medical Centre & $21.07(2.4)$ & $17.19(5)$ & $8.13(2.4)$ & $19.65(2.7)$ \\
\hline Mofid & $21.28(2.6)$ & $17.82(4.1)$ & $7.85(2.6)$ & $19.82(3.1)$ \\
\hline Aliasghar & $21.37(2.6)$ & $17.63(3.7)$ & $7.86(2.2)$ & $19.92(2.9)$ \\
\hline$P$-value ${ }^{a}$ & 0.749 & 0.630 & 0.757 & 0.836 \\
\hline \multicolumn{5}{|l|}{ Parent's age (years) } \\
\hline$\leq 30$ & $21.08(2.7)$ & $17.91(3.5)$ & $7.44(2.4)$ & $19.8(3.1)$ \\
\hline $31-40$ & $21.7(2.2)$ & $17.81(3.9$ & $7.73(2.3)$ & $20.2(3.0)$ \\
\hline $41-50$ & $20.42(2.2)$ & $16.08(4.0)$ & $8.55(2.6)$ & $18.91(2.5)$ \\
\hline$>50$ & $20.47(2.2)$ & $16.76(2.4)$ & $9(1.8)$ & $19.23(1.9)$ \\
\hline$P$-value ${ }^{a}$ & 0.143 & 0.019 & 0.003 & 0.074 \\
\hline \multicolumn{5}{|l|}{ Parent's relation to child } \\
\hline Father & $21.41(2.5)$ & $18(3.8)$ & $7.98(2.6)$ & $19.89(2.8)$ \\
\hline Mother & $21(2.5)$ & $17.1(4.8)$ & $8.02(2.3)$ & $19.65(2.9)$ \\
\hline$P$-value ${ }^{b}$ & 0.916 & 0.109 & 0.227 & 0.747 \\
\hline \multicolumn{5}{|l|}{ Marital status } \\
\hline Married & $21.23(2.5)$ & $17.72(4.5)$ & $7.85(2.5)$ & $19.86(2.8)$ \\
\hline Divorced/widowed & $20.83(2.4)$ & $15.7(3.2)$ & $9.29(1.7)$ & $18.87(2.8)$ \\
\hline$P$-value ${ }^{\mathrm{b}}$ & 0.379 & 0.025 & 0.714 & 0.654 \\
\hline \multicolumn{5}{|l|}{ Parent's education } \\
\hline Illiterate & $22(2.6)$ & $17.33(2.0)$ & $8.66(2.0)$ & $20.33(2.5)$ \\
\hline Elementary school & $21.65(2.4)$ & $16(3.9)$ & $9.3(2.1)$ & $18.88(2.5)$ \\
\hline Middle school & $20.8(3.1)$ & $15.97(4.9)$ & $8.68(2.5)$ & $18.7(2.9)$ \\
\hline High school & $20.7(2.4)$ & $17.74(4.5)$ & $7.85(2.4)$ & $19.8(2.7)$ \\
\hline
\end{tabular}




\begin{tabular}{|c|c|c|c|c|}
\hline \multirow[t]{2}{*}{ Variable } & \multicolumn{4}{|c|}{ Domains } \\
\hline & $\begin{array}{l}\text { Physical Mean } \\
\text { (SD) }\end{array}$ & $\begin{array}{l}\text { Psychological Mean } \\
\text { (SD) }\end{array}$ & $\begin{array}{c}\text { Social relationships } \\
\text { Mean (SD) }\end{array}$ & $\begin{array}{l}\text { Environment Mean } \\
\text { (SD) }\end{array}$ \\
\hline \multicolumn{5}{|l|}{ Parent's education } \\
\hline University & $21.8(2.2)$ & $18.64(3.9)$ & $7.28(2.3)$ & $20.6(2.7)$ \\
\hline$P$-value ${ }^{a}$ & 0.066 & 0.015 & 0.002 & 0.007 \\
\hline \multicolumn{5}{|l|}{ Parent's employment } \\
\hline Housewife & $21.06(2.5)$ & $16.78(3.7)$ & $8(2.3)$ & $19.67(2.9)$ \\
\hline Former employee & $21.53(2.0)$ & $18.5(3.8)$ & $7.5(2.3)$ & $20.52(2.5)$ \\
\hline Manual worker & $20.13(3.0)$ & $18.04(8.4)$ & $9.27(2.6)$ & $18.54(3.3)$ \\
\hline Other & $21.69(2.6)$ & $18(3.2)$ & $7.82(2.5)$ & $19.82(2.6)$ \\
\hline$P$-value ${ }^{a}$ & 0.127 & 0.167 & 0.44 & 0.61 \\
\hline \multicolumn{5}{|c|}{ Monthly household income (US\$) } \\
\hline$\leq 295$ & $20.92(2.7)$ & $17.41(4.9)$ & $8.24(2.5)$ & $19.35(2.8)$ \\
\hline $295-442$ & $21.53(2.1)$ & $18.65(3.8)$ & $6.97(2.3)$ & $21.15(2.7)$ \\
\hline $442.5-590$ & $21.26(2.3)$ & $16.57(3.5)$ & $8.52(2.4)$ & $20.36(2.2)$ \\
\hline$\geq 590$ & $22(3.0)$ & $17.55(3.0)$ & $8(1.8)$ & $18.77(2.6)$ \\
\hline$P$-value ${ }^{a}$ & 0.439 & 0.312 & 0.025 & 0.002 \\
\hline \multicolumn{5}{|l|}{ Residence } \\
\hline Tehran city & $21.37(2.4)$ & $16.9(3.9)$ & $8.29(2.4)$ & $19.44(2.6)$ \\
\hline Outside Tehran city & $21.01(2.6)$ & $17.77(3.8)$ & $7.74(2.4)$ & $20.08(3.2)$ \\
\hline$P$-value ${ }^{\mathrm{b}}$ & 0.707 & 0.474 & 0.796 & 0.034 \\
\hline \multicolumn{5}{|c|}{ Number of children in family with phenylketonuria } \\
\hline 1 & $20.31(2.9)$ & $18.02(4.1)$ & $8.01(2.4)$ & $22.54(2.9)$ \\
\hline 2 & $21.09(3.1)$ & $16(3.1)$ & $8.04(2.3)$ & $22.09(2.4)$ \\
\hline 4 & 20 & 18 & 7 & 24 \\
\hline$P$-value ${ }^{a}$ & 0.51 & 0.1 & 0.918 & 0.702 \\
\hline \multicolumn{5}{|l|}{ Child's age (years) } \\
\hline$<1$ & $21.77(2.5)$ & $20.17(6.3)$ & $7.28(2.7)$ & $20.71(2.5)$ \\
\hline $1-5$ & $21.37(2.7)$ & $17.6(3.6)$ & $7.57(2.5)$ & $19.69(3.0)$ \\
\hline $6-10$ & $21.24(2.4)$ & $16.88(4.0)$ & $8.04(2.3)$ & $19.72(2.9)$ \\
\hline $11-15$ & $20.34(2.6)$ & $16.96(4.1)$ & $8.62(2.5)$ & $19.59(3.5)$ \\
\hline $16-20$ & $21.33(2.2)$ & $16.77(3.8)$ & $8.55(2.1)$ & $19.5(3.5)$ \\
\hline$>20$ & $20.85(2.4)$ & $16(3.0)$ & $8.9(1.9)$ & $18.9(2.2)$ \\
\hline$P$-value ${ }^{a}$ & 0.157 & 0.007 & 0.004 & 0.049 \\
\hline \multicolumn{5}{|l|}{ Child's sex } \\
\hline Male & $21.24(2.6)$ & $17.27(3.9)$ & $8.12(2.4)$ & $19.47(2.8)$ \\
\hline Female & $21.23(2.4)$ & $17.9(4.9)$ & $7.86(2.5)$ & $20.15(2.8)$ \\
\hline$P$-value ${ }^{\mathrm{b}}$ & 0.525 & 0.520 & 0.412 & 0.611 \\
\hline \multicolumn{5}{|c|}{ Child's age at diagnosis of phenylketonuria } \\
\hline 3-5 days & $21.69(2.2)$ & $17.52(4.0)$ & $7.88(2.6)$ & $20.04(2.9)$ \\
\hline$>5$ days & $21.07(2.6)$ & $17.46(4.5)$ & $8.06(2.4)$ & $19.67(2.8)$ \\
\hline$P$-value ${ }^{\mathrm{b}}$ & 0.299 & 0.773 & 0.458 & 0.878 \\
\hline
\end{tabular}

SD: standard deviation.

aANOVA.

${ }^{b}$ t-test.

be different with difference in access to facilities and services and required security and hygiene (28). The parents in our study who were married had a better QoL compared with the divorced and the widow parents.
The social support of a spouse and in a good family environment can help reduce the problems and ease the caring and support of affected children.

Our results indicate that older parents had better QoL 


\begin{tabular}{|c|c|c|c|c|c|}
\hline \multirow[t]{2}{*}{ Domain } & \multirow[t]{2}{*}{ Variable } & \multirow[t]{2}{*}{ Category } & \multicolumn{2}{|c|}{ Unstandardized coefficients } & \multirow[t]{2}{*}{ P-value } \\
\hline & & & B & SE & \\
\hline \multirow[t]{4}{*}{ Physical } & \multirow[t]{4}{*}{ Parent's age (years) } & $\leq 30$ & 1.963 & 0.8465 & 0.020 \\
\hline & & $31-40$ & 2.095 & 0.7823 & 0.007 \\
\hline & & $41-50$ & 0.282 & 0.7965 & 0.723 \\
\hline & & $>51$ (Ref) & - & - & - \\
\hline \multirow[t]{11}{*}{ Psychological } & \multirow{4}{*}{$\begin{array}{c}\text { Parent's education } \\
\text { level }\end{array}$} & Illiterate & 0.138 & 2.2938 & 0.952 \\
\hline & & Elementary school & -2.009 & 1.0409 & 0.054 \\
\hline & & Middle school & -1.773 & 0.8662 & 0.041 \\
\hline & & High school & -0.773 & 0.6796 & 0.255 \\
\hline & \multirow{4}{*}{ Child's age (years) } & University (Ref) & - & - & - \\
\hline & & $<1$ & 2.484 & 1.2465 & 0.046 \\
\hline & & $1-5$ & 1.285 & 1.1266 & 0.254 \\
\hline & & $6-10$ & 0.523 & 1.1780 & 0.657 \\
\hline & \multirow{7}{*}{ Child's age (years) } & $11-15$ & 0.367 & 1.2422 & 0.768 \\
\hline & & $16-20$ & 0.396 & 1.4219 & 0.781 \\
\hline & & $>20$ (Ref) & - & - & - \\
\hline \multirow[t]{11}{*}{ Social } & & $<1$ & -1.485 & 0.7996 & 0.063 \\
\hline & & $1-5$ & -1.466 & 0.7371 & 0.047 \\
\hline & & $6-10$ & -0.996 & 0.7525 & 0.186 \\
\hline & & $11-15$ & -0.193 & 0.7883 & 0.807 \\
\hline & \multirow{5}{*}{$\begin{array}{c}\text { Parent's education } \\
\text { level }\end{array}$} & $16-20$ & -0.064 & 0.9255 & 0.945 \\
\hline & & $>20$ (Ref) & - & - & - \\
\hline & & Illiterate & 0.132 & 1.5479 & 0.932 \\
\hline & & Elementary school & 1.560 & 0.7242 & 0.031 \\
\hline & & Middle school & 0.694 & 0.6029 & 0.250 \\
\hline & \multirow{6}{*}{$\begin{array}{c}\text { Monthly } \\
\text { household income } \\
\text { (US\$) }\end{array}$} & High school & 0.324 & 0.4677 & 0.489 \\
\hline & & University (Ref) & - & - & - \\
\hline \multirow[t]{4}{*}{ Environment } & & $\leq 295$ & 2.024 & 1.0391 & 0.051 \\
\hline & & $295-442$ & 3.303 & 1.0630 & 0.002 \\
\hline & & $442.5-590$ & 3.101 & 1.2226 & 0.011 \\
\hline & & $\geq 590$ (Ref) & - & - & - \\
\hline
\end{tabular}

SE: standard error of the mean.

with regard to the social dimension. These parents had more experience and can build better social relationships. Better educated parents had better QoL for psychological and environment dimensions. A study in the United Kingdom found a positive relationship between higher educated parents and lower level of blood phenylalanine in children (29). A study in Sweden also found that parental education level was significantly associated with blood phenylalanine concentration (30). It appears that better educated parents are better able to manage anxiety, fear and depression, and usually live in a better environment. Parental education with multiple sources of psychosocial support and a positive home environment are likely to be associated with protection against depression (23).

The study had some limitations. Some data were missing for certain demographic variables, such as income and employment, because of the unwillingness of the parents to share such information. These problems were largely resolved by repeated follow-up visits that explained the objectives of the study to parents and reassured them of the confidentiality of information. On the other hand, despite the rareness of the disease, we were able to recruit a large number of parents in the study which adds to its strength. In addition, as a crosssectional study the associations found cannot be taken as causality.

\section{Conclusions}

The QoL of parents of children with phenylketonuria was low. Interv entions are needed to help such parents to cope better with the problems of dealing with a child with phenylketonuria. Family education can increase awareness and improve attitudes of parents. In addition, 
more financial support for families, more involvement by support organizations to help fund people with phenylketonuria, and agreement of insurance organizations to cover the medical costs associated with phenylketonuria would be beneficial.
Funding: This research was supported financially by the Deputy of Research and Technology, Shahid Beheshti University of Medical Sciences, Tehran, Islamic Republic of Iran.

Competing interests: None declared.

\section{Qualité de vie liée à la santé des parents d'enfants atteints de phénylcétonurie dans la province de Téhéran (République islamique d'Iran) \\ Résumé}

Contexte : Les parents d'enfants atteints de phénylcétonurie sont exposés au risque d'avoir une qualité de vie réduite.

Objectifs : La présente étude visait à déterminer la qualité de vie des parents d'enfants atteints de phénylcétonurie dans la province de Téhéran.

Méthodes : L'étude a été menée en 2015 sur des parents d'enfants atteints de phénylcétonurie, qui ont été orientés vers trois hôpitaux pédiatriques publics dotés de services prenant en charge la phénylcétonurie dans la province de Téhéran. Les données ont été recueillies à l'aide de la version abrégée en farsi du questionnaire de l'Organisation mondiale de la Santé sur la qualité de vie (WHOQOL-Bref). L'analyse de la variance, le test t, le coefficient de corrélation de Pearson et la régression linéaire multiple ont été employés pour évaluer le lien entre les domaines de la qualité de vie et les caractéristiques sociodémographiques des parents et des enfants.

Résultats : L'étude incluait 240 parents, dont 55 \% étaient des mères. La qualité de vie des parents dans les domaines psychologique, environnemental et des relations sociales était faible. Des liens significatifs ont été établis entre les éléments suivants : le domaine physique et l'âge de l'enfant au moment du diagnostic de la phénylcétonurie $(p=0,044)$; le domaine psychologique et l'âge des parents $(p=0,019)$, l'âge de l'enfant $(p=0,007)$ et le niveau d'études des parents $(p=0,015)$; le domaine des relations sociales et l'âge des parents $(p=0,003)$, leur niveau d'études $(p=$ $0,002)$, le revenu du ménage $(p=0,025)$ et l'âge de l'enfant $(p=0,004)$; et le domaine environnemental et le lieu de résidence $(p=0,034)$, le niveau d'études des parents $(p=0,007)$, le revenu du ménage $(p=0,002)$ et l'âge de l'enfant $(p=$ 0,049 ). Dans l'analyse multivariée, l'âge et le niveau d'études des parents, l'âge de l'enfant et le revenu du ménage étaient fortement liés à la qualité de vie des parents.

Conclusion : Compte tenu des faibles niveaux de qualité de vie des parents, il est recommandé de favoriser l'accès à l'éducation et d'accroître le soutien financier.

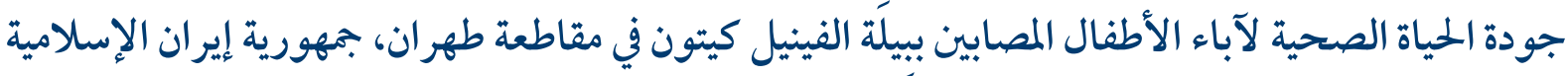 كوروش اعتماد، علي رضا حيدري، آريا ستوده، أمير شايجانراد، أتو سا أخلاوي، مريم عزيزي، رويا نيجات نجسن، مريم بجلار، منصورة لطفي ملهي}

$$
\begin{aligned}
& \text { الخلفية: آباء الأطفال المصابين ببيلة الفينيل كيتون مُعرضون لخطر انخفاض جودة الحياة. }
\end{aligned}
$$

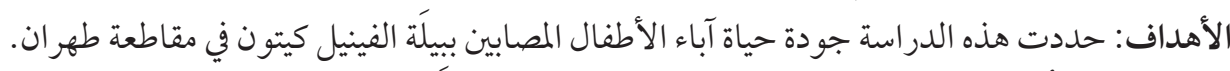

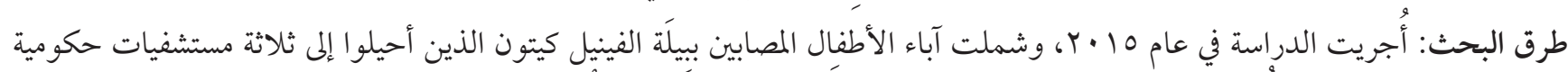

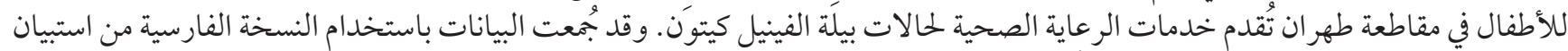

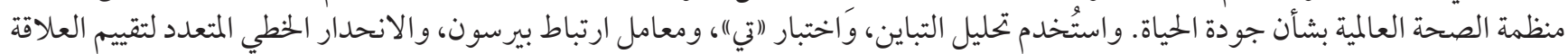

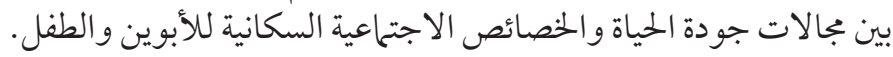

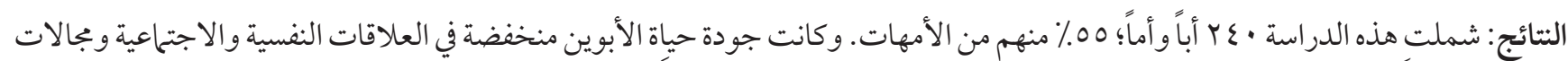

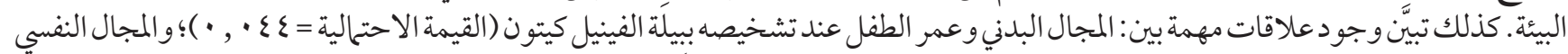

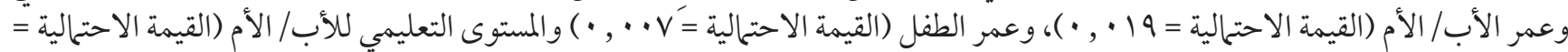

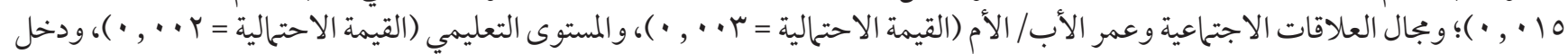

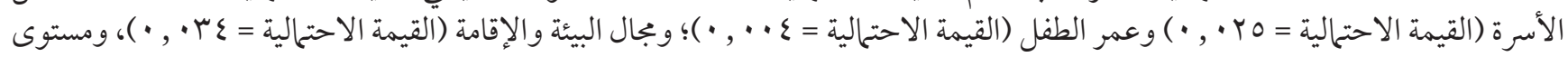

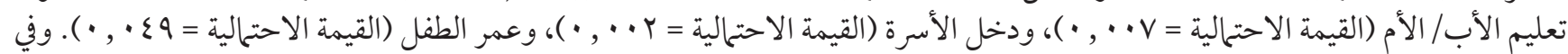

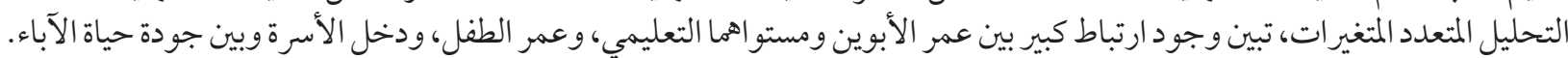

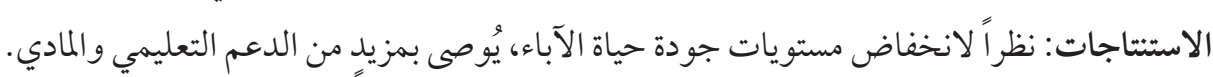




\section{References}

1. Banta-Wright SA, Kodadek SM, Steiner RD, Houck GM. Challenges to breastfeeding infants with phenylketonuria. J Pediatr Nurs. 2015;30(1):219-26. https://doi.org/10.1016/j.pedn.2014.05.003

2. Soleymani Z, Keramati N, Rohani F, Jalaei S. Factors influencing verbal intelligence and spoken language in children with phenylketonuria. Indian Pediatr. 2015 May;52(5):397-401.

3. Regnault A, Burlina A, Cunningham A, Bettiol E, Moreau-Stucker F, Benmedjahed K, et al. Development and psychometric validation of measures to assess the impact of phenylketonuria and its dietary treatment on patients' and parents' quality of life: the phenylketonuria - quality of life (PKU-QOL) questionnaires. Orphanet J Rare Dis. 2015;10:59. https://doi.org/10.1186/s13023015-0261-6

4. Jusiene R, Kucinskas V. Familial variables as predictors of psychological maladjustment in Lithuanian children with phenylketonuria. Med Sci Monit. 2004;10(3):102-7.

5. Eijgelshoven I, Demirdas S, Smith TA, van Loon JM, Latour S, Bosch AM. The time consuming nature of phenylketonuria: a cross-sectional study investigating time burden and costs of phenylketonuria in the Netherlands. Mol Genet Metab. 2013;109(3):237-42. https://doi.org/10.1016/j.ymgme.2013.05.003

6. Bahramnezhad F, Asadi Noughabi A, Sief H, Mohammadi Y. [Quality of life in the patients with coronary bypass graft]. Iran J Nurs Res. 2012;7(26):34-41. [In Farsi]

7. ten Hoedt AE, Maurice-Stam H, Boelen CC, Rubio-Gozalbo ME, van Spronsen FJ, Wijburg FA, et al. Parenting a child with phenylketonuria or galactosemia: implications for health-related quality of life. J Inherit Metab Dis. 2011;34(2):391-8. https://doi. org/10.1007/s10545-010-9267-3

8. Sajadi SA, Ebadi A, Moradian ST. Quality of life among family caregivers of patients on hemodialysis and its relevant factors: a systematic review. Int J Community Based Nurs Midwifery. 2017;5(3):206-18.

9. Thimm E, Schmidt LE, Heldt K, Spiekerkoetter U. Health-related quality of life in children and adolescents with phenylketonuria: unimpaired HRQoL in patients but feared school failure in parents. J Inherit Metab Dis. 2013;36(5):767-72. https://doi. org/10.1007/s10545-012-9566-y

10. Simon E, Schwarz M, Roos J, Dragano N, Geraedts M, Siegrist J, et al. Evaluation of quality of life and description of the sociodemographic state in adolescent and young adult patients with phenylketonuria. Health Qual Life Outcomes. 2008;6:25. https:// doi.org/10.1186/1477-7525-6-25

11. Jusiene R, Kucinskas V. Familial variables as predictors of psychological maladjustment in Lithuanian children with phenylketonuria. Med Sci Monit. 2004;10(3):CR102-7.

12. Fidika A, Salewski C, Goldbeck L. Quality of life among parents of children with phenylketonuria (PKU). Health Qual Life Outcomes 2013,11:54. https://doi.org/10.1186/1477-7525-11-54

13. Hatzmann J, Heymans HSA, Ferrer-i-Carbonell A, van Praag BMS, Grootenhuis MA. Hidden consequences of success in pediatrics: parental health-related quality of life-results from the care project. Pediatrics. 2008122(5):e1030-8. https://doi.org/10.1542/ peds.2008-0582

14. WHOQOL-BREF.Introduction, administration, scoring and generic version of the assessment. Field trial version. Geneva: World Health Organization; December 1996 (https://www.who.int/mental_health/media/en/76.pdf, accessed 6 August 2019).

15. Jahanlou AS, Karami NA. WHO quality of life-BREF 26 questionnaire: reliability and validity of the Persian version and compare it with Iranian diabetics quality of life questionnaire in diabetic patients. Prim Care Diabetes. 2011;5(2):103-07. https://doi. org/10.1016/j.pcd.2011.02.001

16. Nedjat S, Montazeri A, Holakouie K, Mohammad K, Majdzadeh R. Psychometric properties of the Iranian interview-administered version of the World Health Organization's quality of life questionnaire (WHOQOL-BREF): a population-based study. BMC Health Serv Res. 2008;8:61. https://doi.org/10.1186/1472-6963-8-61

17. Yousefy AR, Ghassemi GR, Sarrafzadegan N, Mallik S, Baghaei AM, Rabiei K. Psychometric properties of the WHOQOL-BREF in an Iranian adult sample. Community Ment Health J. 2010;46(2):139-47. https://doi.org/10.1007/s10597-009-9282-8.

18. Hatzmann J, Valstar MJ, Bosch AM, Wijburg FA, Heymans HS, Grootenhuis MA. Predicting health-related quality of life of parents of children with inherited metabolic diseases. Acta Paediatr. 2009;98(7):1205-10. https://doi.org/10.1111/j.16512227.2009.01269.x

19. Mahmoudi-Gharaei J, Mostafavi S, Alirezaei N. Quality of life and the associated psychological factors in caregivers of children with PKU. Iran J Psychiatry. 2011;6(2):66-9.

20. Arnaud C, White-Koning M, Michelsen SI, Parkes J, Parkinson K, Thyen U, et al. Parent reported quality of life of children with cerebral palsy in Europe. Pediatrics. 2008;121(1):54-64. http://doi.org/10.1542/peds.2007-0854

21. Khayatzadeh M. [A comparative study about quality of life in mothers of children with cerebral palsy, mental retardation and mothers of normal children]. Sci Res J Shahed Univ. 2009;16(83):1-11. [In Farsi]

22. Beckhauser MT, Peruchi MM, Rozone de Luca G, Lin K, Esteves S, Vilarinho L, et al. Neuroradiological findings of an adolescent with early treated phenylketonuria: is phenylalanine restriction enough? Clin Pract. 2011;1(2):e25. https://doi.org/10.4081/cp.2011. e25 
23. Gunduz M, Arslan N, Unal O, Cakar S, Kuyum P, Bulbul SF. Depression and anxiety among parents of phenylketonuria children. Neurosciences. 2015;20(4):350-6. https://doi.org/10.17712/nsj.2015.4.20150319

24. Sajedi F, Nazi S, Rohani F, Biglarian A. 2014. [Motor development skills of 1-4-year-old Iranian children with early treated phenylketonuria]. J Rehabil. 2014;14(S2):100-6. [In Farsi]

25. Bosch AM, Alberto B, Cunningham A, Bettiol E, Moreau-Stucker F, Koledova E, et al. Assessment of the impact of phenylketonuria and its treatment on quality of life of patients and parents from seven European countries. Orphanet J Rare Dis. 2015;10(80):1-14. https://doi.org/10.1186/s13023-015-0294-X

26. Nejat S, Montazeri A, Holakouie-Naieni K, Mohammad K, Majdzadeh SR. [Quality of life of Tehran's population by WHOQOL-BREF questionnaire in 2005]. Hakim Health Sys Res. 2007;10(3):1-8 [in Farsi].

27. Lee YJ. Subjective quality of life measurement in Taipei. Build Environ. 2008;43(7):1205-15. https://doi.org/10.1016/j.buildenv.2006.11.023

28. Seyedan F, Oshtobini AS. [Evaluating the relationship between access to community services and facilities, neighborhood safety and health, and life quality of women living in Tehran (with an emphasis on special needs of women in District 2 of Tehran)]. J Geogr Urban Space Dev. 2014;1(1):65-76 [In Farsi].

29. Macdonald A, Davies P, Daly A, Hopkins V, Hall SK, Asplin D, et al. Does maternal knowledge and parent education affect blood phenylalanine control in phenylketonuria? J Hum Nutr Diet. 2008;21(4):351-8. https://doi.org/10.1111/j.1365-277X.2008.00891.X

30. Olsson GM, Montgomery SM, Alm J. Family conditions and dietary control in phenylketonuria. J Inherit Metab Dis. 2007;30(5):708-15. https://doi.org/10.1007/s10545-007-0493-2 